\title{
How Powerful are Transnational Elite Clubs? The Social Myth of the World Economic Forum
}

\author{
JEAN-CHRISTOPHE GRAZ
}

This article analyses the extent and nature of private authority in global political economy by examining one of its most publicised instances, the World Economic Forum (WEF). ${ }^{1}$ In Davos, Switzerland, the annual meetings of the WEF have attracted the world economic and political élite for more than 30 years. Appraisals of the WEF diverge widely. For many years, Le Monde Diplomatique, the French monthly close to the anti-neoliberal globalisation movement, has described the World Economic Forum as 'the meeting place of the masters of the world [which] has undoubtedly become the centre of hyperliberalism, the capital of globalisation, and the main home of the "pensée unique", .2 George Soros, the well known hedge-fund manager turned philanthropist, has described the meetings of Davos, of which he is a regular participant, as a 'big cocktail party'. ${ }^{3}$ These contrasting views on the influence and power of the WEF in global politics and economy mirror the position of those holding such claims: those closely associated with the Forum are inclined to deny its power and those fiercely opposed are likely to emphasise its overarching influence. From a theoretical perspective, however, these opposing views express disagreement on one outstanding feature of the changes associated with 'globalisation': the significance of new agents in the global political economy beyond states and markets.

With the rising importance attributed to non-state actors in world politics, the issue of private authority has gained increasing prominence in the recent literature on contemporary international relations. This body of literature explores the relationship between political authority and economic power by considering its articulation with new patterns and agents that shape the political economy of the present world. The field of enquiry is broad: it encompasses the study of private global corporate actors as well as non-governmental organisations (NGOs), the appropriation of knowledge and its diffusion through media networks and think-tanks as well as transnational organised crime and neo-mercenary trends embodied in private military companies. ${ }^{4}$ In her pioneering investigations of these new large unexplored areas of research, Susan Strange suggested that future analyses should explore more precisely 'the extent and

Jean-Christophe Graz, Institut d'études politiques et internationales, Université de Lausanne, CH-1015 Lausanne, Switzerland. 
limits of non-state authority'. ${ }^{5}$ In the burgeoning literature, however, the object of private authority, the nature of its power and its relation to the state remain unclear. Following Cutler, the prospects for locating authority in the global political economy now turns on the all-inclusive 'nexus between economics and politics, private and public activities, and local and global political economies' 6

In respect of world-wide élite groups, critics are prone to denounce their undemocratic power, whilst more mainstream opinion is keen to condemn the conspiracy theory that underpins such a view and would even deny that such groups may have any relevance in research on private authority. The search for evidence of the power of such groups is a conundrum for scholarly analyses. The influence of an élite club on a particular issue of global politics hinges, by definition, on loose and informal channels of power. This rules out the conclusions which might be drawn from an evidence-based enquiry following a relational conception of power focused on the links between the resources and control over outcomes. As Stone argues with regard to global think-tanks, establishing such causal nexus is 'fraught with methodological problems'. ${ }^{7}$ A relational conception of power cannot retrace the links between a position held within the confinement of a club to its eventual translation into a formal political decision. A structural conception of power emphasises, in contrast, the environment in which these strategic interactions take place. ${ }^{8}$ Transnational historical materialist scholarship, in particular, has focused on the significant role of élite clubs in shaping world politics. ${ }^{9}$ From this perspective, such clubs belong to the political organisation of capitalism on a transnational basis. Most studies remain elusive, however, as to how such clubs concretely impinge on society and on where lie the limits of their power. In this respect, the case of the WEF is frequently mentioned in the literature, but there has as yet been no substantial research done on its role in the present world. ${ }^{10}$

This article argues that the power exercised by transnational élite clubs is intrinsically bounded by the concrete modalities of their practice. By assuming that they de facto involve a high constituency of power, it proposes to shift the focus of investigation away from a search for evidence of power towards a perspective that could be defined as a hermeneutics of limits. Building upon the concept of social myth forged by the French thinker Georges Sorel, it posits that the separation of transnational élite clubs from the public sphere constitutes both their strength and their weakness. Their organisational principles entail a clear-cut cleavage between a coopted minority and the formal institutions of representative democracy. This scission is supposed to arouse the sense of an exclusive community and, therefore, to reinforce the idea of its shared responsibility towards the future of the world. Yet it also impinges upon the capacity to institutionalise the views held within those confined circles. This has been well illustrated by the difficulties that the WEF has encountered recently. The more the influence of the WEF is perceived, the harder it will be for it to pretend to a legitimate role in the shaping of world-wide issues in the future.

The argument is divided into six sections. The first provides a brief overview of the scholarship on transnational élite clubs, with a particular emphasis on transnational historical materialist approaches. The second elaborates the relevance of the Sorelian concept of social myth to complement those approaches. 
The third introduces the case of the WEF. The fourth section provides an historical account of its origins and shows how it was from the outset an attempt to forge a synthesis between social myth and hegemonic planning. The fifth examines how this original setting developed into a success story. The sixth analyses the current difficulties of the Forum, the limits of its influence and its inability to engage reforms securing its future. The conclusion wraps up the argument and considers the implications for our understanding of global change and power, with particular emphasis on the emergence of private authority in international affairs.

\section{The structural power of transnational élite clubs}

Activist groups and academic scholars have explored how transnational élite clubs may play a significant role in world politics. Whilst the former tend to undertheorise the power of those clubs and may use questionable evidence in pursuit of their arguments, the latter tend to undertheorise the practice of those clubs and have provided few detailed studies on the way they shape the political economy of the present world. Studies of transnational élite clubs also reflect different schools of thought. Liberal approaches mostly focus their analysis on the role of leaders on issues of coordination and efficiency. ${ }^{11}$ Constructivists address social settings, institutions and identification processes that impinge on the social construction of collective action. ${ }^{12}$ Poststructuralists focus more specifically on the link between discursive practices and their disciplinary effects. ${ }^{13}$ Each of these approaches contributes on its own terms to a better understanding of the role of élites in solving collective action dilemmas, in disciplining society through discursive power, or in mediating between the increasingly competitive spheres of authority in the international realm. They fail, however, to capture the structural power involved in the interactions between states and non-state actors. It is not a matter of resources, outcomes and distribution of relational power focused on decision-making processes across issue areas; nor of additional layers of governance whose functions would complement traditional state functions. As suggested by Higgott et al., 'the relationships between states and non-state actors [are] sometimes conflicting, but often symbiotic'. ${ }^{14}$

Transnational historical materialist approaches provide a persuasive explanation of why state and non-state actors should be considered as a joint expression of one broad configuration of structural power. From this perspective, transnational élite clubs are class organisations belonging to the means of reproduction of the power of capital just as states do. They are class organisations in that they can be defined in terms of their relationship to the structures of capitalist societies. As suggested by Cox, however, class analysis is not per se Marxism: more broadly, the concept of class implies that relations of social and political inequalities "converge into the relations of the production process'. ${ }^{15}$ As Sklair points out with regard to the salience of the transnational capitalist class, the concept of class sheds light on the political agency of globalisation: 'globalization, like its main driving force, capitalism on a world scale, does not just happen. It is thought out, organized, managed, promoted, and 
defended against its opponents by identifiable groups of people working in identifiable organizations.' ${ }^{16}$ Being enshrined in the class structure of capitalist societies, transnational élite clubs reproduce the structural inequality between those who control the physical and financial assets of the means of production and those who create surplus value to accumulate these assets. Their contribution to the power of capital takes two interrelated courses. On the one hand, they reinforce the formation of an overall capitalist class consciousness that transcends inter-capitalist rivalries and embraces the global dimension of the capitalist mode of production 'based on the exploitation of others' work' ${ }^{17}$ On the other hand, they constitute a privileged locus for expanding this worldview to subordinated classes in such a way that it could be seen as one expression, among others, of the general interest.

According to Gill, transnational élite clubs constitute a 'strategic element within globalizing capitalism'. ${ }^{18}$ A proper theorisation of their power differs from a conspiracy theory:

These private international relations councils are not shadow governments of plutocrats manipulating international relations. Rather, they are consciousness-raising forums where individuals representing elements of the state and civil society in affiliated countries can come to know and influence each other.... Private councils are part of a much wider international process of elite familiarisation and fraternisation, mutual education and, broadly speaking, networking. ${ }^{19}$

Gill draws upon Gramsci's writing on the role of intellectuals in developing class consciousness and on some of his less known remarks on the status of élites in representative democracies. According to Gramsci, the liberal principle of one-man-one-vote dismisses the fact that "ideas and opinions are not spontaneously "born" in each individual brain: they have had a centre of formation, of irradiation, of dissemination, of persuasion' ${ }^{20}$ Van der Pijl also identifies transnational planning groups as class organisations playing a crucial role in 'developing common strategies and adjusting the hegemonic concept of control'. ${ }^{21}$ According to this author, the World Economic Forum can even be considered as 'the most comprehensive transnational planning body operative today, ... a true International of capital, the first identifiable forum in which concepts of control are debated and if need be, adjusted, on a world scale'. ${ }^{22}$

It has now been widely recognised in the literature that Gramscian-inspired interpretations of hegemony closely related to transnational historical materialist approaches provide ways to emphasise the importance of consent in a structural understanding of power on a global scale. Whilst these approaches offer the analytical tools to theorise the overall coherence required to situate the relationship between state and non-state actors, few detailed studies of transnational élite clubs have so far been inspired by such a perspective. With the exception of Gill's study of the Trilateral Commission and van Apeldoorn's research on the European Round Table of Industrialists, ${ }^{23}$ such clubs are frequently mentioned in the literature, but always briefly, with no substantial research, and, like activist dissemination of information, with a tendency to reproduce in loops a limited 
number of original sources. This can be partly explained by the factual limit in the number of instances whose influence is situated beyond the traditional role of lobbies. The methodological problems related to the access to sources, be it confidential documents or global élites for interview, constitute another difficulty. Moreover, according to van der Pijl, a detailed study focused on one organisation would underestimate the overlapping and metamorphoses that characterise transnational planning groups in the longue durée: 'class organisations constantly readjust to the real balance of forces confronting them' ${ }^{24}$ The World Economic Forum, as one of the most prominent venues in this context, is nevertheless sufficiently important to deserve its own detailed analysis.

More importantly, the existing studies fail to capture the specific practices of transnational élite clubs. The Gramscian concept of hegemony and the evidence of networking among élites on an international scale do not specifically explain why some networks are more successful than others. It is crucial to identify what concretely enables the hegemonic function of certain instances and not others. What is lacking, then, is a proper theory of the process of socialisation in which such practices of power take place.

\section{Social myth and hegemonic power}

The myth created by the gathering together of a high-powered network plays a crucial role in both the strength and weakness of transnational élite clubs. The notion of myth does not here refer to the part of illusion (as strong as that might be) conveyed by élite clubs. ${ }^{25}$ It refers to the concept of social myth forged by Georges Sorel in his Reflections on Violence (first published in 1906) and revisited by Gramsci in his writings on hegemony. As Augelli and Murphy have pointed out, for international relations scholars influenced by Gramsci, Sorel's concept provides insights on how leaders attempt 'to motivate collective political action that would maintain or transform a significant aspect of world order' ${ }^{26}$ Although Sorel never properly defines social myths, he refers on several occasions to the 'expression of a will to act', 'the expression of the conviction of a whole group in the language of movement' or even to a 'sublime undertaking' ${ }^{27}$ Ultimately, it is the scission of one class from another in an environment of all-encompassing collective passion which, in Sorel's view, raises consciousness. ${ }^{28}$

The concept of social myth aims, then, to capture the mobilising power prompted by the formation of collective consciousness which takes place, as in classical drama, within an extreme compression of time, site and action. This concept inspired the early thoughts of Gramsci on proletarian auto-emancipation ('ouvrierism'). Later, despite the bolshevisation of the Italian Communist Party in the 1920s banning the merits of proletarian spontaneism, it gained ground in Gramsci's concept of historic bloc as a congruence of social forces politically organised to exert hegemonic power through consent rather than through coercion. According to Sorel, much as primitive Christianity held to the myth of the second coming as the driving force of its struggle against the Roman empire, the general strike can be viewed as a social myth fostering class consciousness among workers and reinforcing their revolutionary fervour. It 
draws its strength from the rupture with a culture of repeated compromises and, consequently, the clear case for a separation of the proletariat from other social classes: 'society is truly divided in two camps, and only two, on the battle field'; accordingly, a social myth 'locks itself ... into one indivisible unit' ${ }^{29}$

Transnational élite clubs provide a mirror image of the same principle. As Cox points out in respect of the ways social myths can be a feature of many historical and contemporary groups, 'the content of the myth is less important than its mobilizing power for sharpening the lines of conflict and stimulating action for change'. ${ }^{30}$ By drawing a clear line between those included and those excluded, élite clubs rely on a total cleavage between those sufficiently powerful to interact behind closed doors and those having no place in such exclusive arenas. The mobilisation of creative forces takes place in a confined space cut off from the public sphere. Due to the de facto position of power held by the participants, the privatised environment of élite clubs is vested with the capacity to bring about change in society at large. This is what catch-phrases like 'meeting place of the masters of the world' attempt to convey.

Yet the concept of social myth may explain not only the power of transnational élite clubs, but also its limits. It underscores a spontaneous and non-institutional understanding of social practice. The impetus for social change rests on the realm of the possible as available to individuals involved in the action. It can be the expression of their 'will to act', but not the will of the social forces which propelled them. It can give way to some organisational outcome in the form of initiatives, working groups, councils or task forces. To be more than mere managerial outcomes, it must engage with the more formal processes of political institutionalisation and the role of the state. In his study of the 'Dreyfus Affair', which so deeply affected France's Third Republic at the turn of the twentieth century, Sorel was well aware that a spontaneous understanding of social myth would result in a quandary. He fully recognised the relationship that prevails between the rise of consciousness taking place in a social myth and the longer planning process needed to build a political and ideological leadership conducive to deeper institutional change. In his view, civil law was the key target: he noted that in a situation of total calm, when the future is assured, one can educate the new generation to the idea that the new regime rests on incontestable theories of civil law'. ${ }^{31}$ Although denied by Gramsci, these observations suggest that Sorel saw an intimate connection between social myth and hegemonic leadership. ${ }^{32}$ In his reading they appear as mutually related and stretch along a continuum bounded, on the one hand, by the pure vanity of actors falsely believing themselves autonomous agents of change and, on the other, the public institutions providing a broad measure of consent on a global and comprehensive scale to the dominance of the particular configuration of forces in control of the financial and material basis of social life. Whereas the conquest of hegemonic leadership relies on the mobilising effect of social myths, social myths as such are insufficient for achieving hegemony. As Charzat points out, 'great collective passion ... can accelerate the realisation of the new society, provided that it was preceded by a patient and systematic engagement with existing institutions' ${ }^{33}$

Thus, in making this argument about the limits of power of transnational élite clubs, two basic assumptions are involved. First, the ability of transnational élite 
clubs to exercise real power beyond private deals and one-off trade-offs is mediated by public institutions and social mobilisation. Although they can pool huge resources, the outcome will always have unintended consequences following the mobilising power of social forces excluded from the definition of the collective will supposedly shared within the confines of the club. Second, the limits of their power is circumscribed by what, in Gramscian terms, would be called transformism. This concept refers to a particular feature of 'passive revolution' where the introduction of change does not involve an active mobilisation of popular forces. Instead it leads toward a crystallisation of unresolved contradictions brought together in the widest possible coalition of interests, in particular through the cooptation of potential leaders of subaltern groups and the assimilation in a more innocuous form of their most subversive discourse. ${ }^{34}$ Transformism is an integral part of a managerial understanding of power seeking to rebalance the deep social tensions arising out of global capitalism. ${ }^{35}$ Some initiatives may indeed lead to real outcomes once they have passed into more formal channels of public life. Yet such an informal network of influence can only rarely replace a more comprehensive and socially-defined concept of power in the global political economy.

It is within this framework that the role of the World Economic Forum must be viewed. The remainder of this article will attempt to assess how the social myth of capitalist consciousness has underpinned the successful history of the WEF, how far it is inscribed in the various institutions providing hegemonic leadership to the present world, and to what extent the problems that the WEF has encountered more recently reflect the intrinsic limits to the power of such closed transnational élite clubs cut off, as they are, from the representative institutions of public life.

\section{The case of the World Economic Forum}

The official history of the World Economic Forum conveys the social myth of spontaneous change effected by the sense of community shared among the WEF participants. The grounding of the myth lies in the close merger of economic and political leadership within the three unities of classical drama: place, time and action. The unity of place rests on the difficulty of access to the Alpine resort, which for the period of the conference looks like an enclosed site. By metonymy, Davos $i$ s the World Economic Forum for a week every winter. The unity of time derives from the relatively uncompressible time spent by the élites taking part in the gathering due to this difficulty of access. Apart from the 'super-VIPs' who come and go by helicopter, participants generally stay for at least three days. Finally, the unity of action hinges on the absence of the distractions to be found in the global cities usually frequented by transnational élites. In Davos, apart from skiing, there is nothing else to do during the time of the conference except meet other participants.

According to the self-proclaimed vision of the WEF, it is the collective passion emanating from such a high-density networking environment that creates the 'spirit of Davos': the magic of impromptu meetings ends up implementing the official WEF mission of being 'committed to improving the state of the 
world'. The social myth of capitalist consciousness has indeed sustained the success story of the WEF. The concrete practice of the annual meetings of the WEF suggests, however, that it is less a planning organisation of global capitalism than, more modestly, a polymorph platform of intermediations on the new frontiers of capitalism. This assumption is reflected in the motivations of the participants that stretch along a continuum from pure vanity to strategic planning, passing by the search for the trend in fashionable topics, the establishment of key contacts, cutting deals, or improving their influence on some policy process. According to Lewis Lapham, the former editor of Harper's Magazine who summarised his experience in a short book, the ritual of Davos is so desperate that it resembles the Agony of Mammon in Wagner's Parzifal. ${ }^{36}$ Yet, for a frequent-flyer like Jacques Attali, the former special adviser to the French President François Mitterrand, the Forum is 'a time-saving hotel keeper of business trips'. ${ }^{37}$ Finally, according to an academic 'Forum Fellow', 'nobody comes here to think; some come to do business and we do not see them; some come on the contrary to use the Forum as a powerful launching pad for balloons; and everyone is playing a mirror game to measure the wavelength of the moment'. 38

The following account suggests that the power embodied by such closed transnational élite clubs has intrinsic limits, because of its divorce from the legitimate institutions of public life. We shall stress that the social myth of the Forum does not exist independently from the various instruments of a more institutionalised process of hegemonic formation. The fact that the WEF is institutionally cut off from the formal public institutions of the global political economy is what creates both its strength and its weakness.

\section{The origins of Davos}

Klaus Schwab, Founder-President of the WEF, is particularly anxious to personify on his own the origin of a spontaneous social myth. The official history of the beginning of the WEF invariably mentions the personal initiative and the financial risk taken by him. According to the WEF website, 'in 1970, Klaus Schwab, Professor of Business Administration, took the initiative and the personal risk to convene Europe's chief executives to an informal gathering in the Swiss mountain town of Davos in January 1971, to discuss a coherent strategy for European business to face challenges in the international marketplace'. 39 This story circulates year after year in the media coverage of the WEF. Yet the historical evidence clearly impairs this version and gives considerably more weight to the institutional context in which the creation of the WEF took place.

The World Economic Forum has its origins in the Centre d'Etudes Industrielles (CEI) of Geneva. Aside from IPSOA (Istituto Post-Universitario per gli Studi di Organizzazione Aziendale) established in 1952 in Turin by Fiat, IMEDE (Institut pour l'Etude des Méthodes de Direction d'Entreprise) founded in 1957 by Nestlé in Lausanne, Switzerland, and INSEAD (Institut Européen d'Administration des Affaires) set up in 1959 by the Paris Chamber of Commerce, the CEI was one of the four executive business schools that had a key 
role in the managerial revolution following the Marshall Plan in Europe. It was created in 1946 by Alcan-the Canadian subsidiary created for the international operations of the American aluminium firm Alcoa-as a training centre for the future international careers of its managers. In the late 1960s the CEI was loosening its relationship with Alcan and was becoming a key pole of competence in management with worldwide ties. ${ }^{40}$

It is against this background that Klaus Schwab joined other new young staff in 1969 to give additional purchase to the restructuring of the school. ${ }^{41}$ As a junior member of faculty, he was quickly invited to take charge of the fastidious preparation of the 25th anniversary of the CEI planned for 1971. Instead of a standard dinner, he suggested celebrating the event by organising a large conference. The idea of Davos came through the contacts he had there through his father, a German industrialist. The format of the conference, however, was not original. Professional conferences organised in remote areas along the principle of the three unities of place, time and action were already fashionable during the 1960s. Moreover, the organisation and the content of the panels of the first Davos symposium were close to the topics offered in the programmes of the CEI and most of the invited speakers had already lectured in some CEI programmes. The conference could not have attracted the big names of the American business schools and a number of high profile European industrialists without the reputation of the CEI, considered at the time as the most prestigious management school in Europe and the only truly international one. ${ }^{42}$

Whilst the name and the address book of the CEI are closely related to the first Davos symposium, Klaus Schwab conceived with one of his associates, Duri Capaul, an artful legal artifice to keep control of the event. They created a private company, International Education Services, and sent a letter to the Director of the CEI to present the contractual relationships that the CEI would have with that company for the organisation of the event. It remains unclear whether the Director realised that with his signature he agreed to invert the roles and responsibilities of both parties. However that may be, the terms and conditions of the arrangement signified that it was not the CEI that gave to its most junior faculty member the task of organising the celebrations of the 25th anniversary of the Centre but, on the contrary, that company which was in charge of the event:

International Education Services (IES), as the initiator and organiser of the European Management Symposium (EMS), owns all rights concerning the realisation of the EMS.

IES will have full rights to use CEI's name, and unlimited use of its know-how [for the organisation of the symposium] ...

We have a direct contract with Klaus Schwab, making him fully responsible for the project of EMS. We understand that all decisions at the CEI regarding the symposium will be delegated to KS [Klaus Schwab]. ${ }^{43}$

This legal basis granted Klaus Schwab the right to create at the time of the first symposium the not-for-profit Foundation of the European Management Forum as 
the umbrella organisation that would subsequently assure him complete independence from the CEI for the future.

This was the true beginning of the World Economic Forum. The CEI was well aware that the success of the event was beyond the dissemination of the latest management techniques of the USA throughout the European entrepreneurial culture. The need for some loose and informal framework of strategic business planning was strongly felt: 'although the Symposium did not come up with resolutions or proposals - it was not meant to-it did leave with this group of executives the idea that perhaps businessmen need such vehicles for planning on a broad front, at least to parallel soon the planning mechanisms so briskly established by governments, within and across borders'. ${ }^{44}$ In the only major newspaper article covering the event, the message was well received: 'the manager of tomorrow must be a social architect'. ${ }^{45}$

Hence, from the outset, the Forum explored the groundwork for an original synthesis between social myth and hegemonic planning. The specific club atmosphere in which élites can share their views should not only be used for the particular interests of the various fractions of capital, but also for the general interest of capitalism. It is against this background that the Forum quickly expanded its scope beyond managerial questions to develop an agenda including macroeconomic, political and strategic issues.

\section{The golden years of the myth}

In 1987 the Foundation of the European Management Forum changed its name to the World Economic Forum. The new denomination reflects an important shift in the internal organisation and objectives of the Foundation. Until then, the Board was made up of four low profile associates of Klaus Schwab. Its membership would henceforth include chief executive officers (CEOs) from major multinational corporations such as Nestlé, Dell, Coca-Cola, BP, ABB, Vivendi and Enron. ${ }^{46}$ The core organisational and commercial basis of the Forum would no longer rely on management experts paid to offer their knowledge to business leaders; the largest multinational corporations would henceforth pay to take advantage of a network that condenses in one place and at one time the world-wide coverage of their operations and to disseminate their own worldview. ${ }^{47}$ It is in this respect that the Foundation has increasingly mingled management scholars with consulting professionals, columnists, high profile CEOs and political leaders. As the former Vice-President of the Board notes, 'the strategic thinking at the origin of Davos would henceforth abandon its intellectual roots to embrace the thinking of the big names'. ${ }^{48}$

In the late 1980s and throughout the 1990s there was a large increase in the number and prestige, as well as in the geographical and sectoral origins, of the participants. The number of participants moved from less than a thousand to more than three thousand, half of whom are invited by the Foundation to animate panels, lend a high profile to the network and ensure the highest possible repercussion in élite circles, the media and broader public opinion. ${ }^{49}$ These guests include several hundreds of political leaders and high-ranking officials, as well as 'Forum Fellows' chosen from academic scholars, executive officers of research foundations and around 500 editors and columnists of press groups 
around the world. The apogee of the prestige of participants to the Forum was probably reached in 2000 when for the first time the President of the United States, William J. Clinton, took part in the event with nine other political leaders of the Organisation of Economic Cooperation and Development (OECD).

The geographical origin of the participants reflects three distinct features. ${ }^{50}$ First, the prestige of Davos led to a rapid development of regional forums that strengthened the relationship between the core participants of the annual meetings in Davos and various regional business networks. This trend was also extremely useful for attracting new participants to the annual meetings. Second, not surprisingly, the Americans gained a significant prominence all through the 1990s to constitute at the end of the decade more than a third of the participants. According to the Financial Times, when in 2002 the Forum took place for the first time out of Davos and moved to New York, 'the US corporate presence was so overwhelming that it [the forum] no longer had the feel of a truly international gathering'. ${ }^{51}$ Finally, medium-sized countries are generally over represented. Ironically, this focus on the new frontier of capitalism often takes place in the year preceding the crisis that would hit the country pushed to the forefront. ${ }^{52}$ As with the Regional Forums, these participants usually do not show much inclination towards the philanthropic message of Davos. As one regular academic participant to the annual meetings notes with euphemism, 'the Forum invests heavily in the emerging markets, like Turkey, Portugal, Mexico, or South Africa, but a number of participants from these countries are second-tier' ${ }^{53}$

The sectoral origins of the participants to the Forum reflect the increasing power of financial capital and the boom in information and telecommunication sectors that took place during those years. An ever-increasing number of CEOs from multinational banks fraternise not only with CEOs of major industrial firms, but also with finance ministers and governors of central banks, be it from OECD or developing countries. Moreover, the huge logistical challenge of the annual meeting has always constituted a showroom for the technology of the future. The meeting is used to demonstrate its potential and to convince business and political leaders to adopt a coherent strategy for attaining a level of profitability after the huge sums already spent in research and development. Klaus Schwab, who was trained as an engineer, seems to be fascinated by technology. According to the following pronouncement, it could provide vital answers to the most urgent problems of the world:

If the WEF is 'committed to improve the state of the world', it must address its most crucial challenges by keeping pace with its latest developments. While the whole way in which societies lived radically changed with the Industrial Revolution some 150 years ago, we now face a twin revolution of Electronics and Genetics. The E-revolution marks a radical shift in with whom we communicate. The G-revolution marks a radical shift of who we are. The key challenge is thus how to maintain a collective identity. $^{54}$

Notwithstanding the self-congratulatory tone of the message, this ready-made 
language suggests that the technological showroom of the annual meetings of Davos is clearly associated with a general interest in the future of capitalism.

\section{The fading star of the myth and the fallacy of hegemonic workshops}

Be that as it may, the social myth of the annual meeting of Davos has recently been impaired. What once made the success of the WEF is on the verge of engendering its failure. This is reflected in both the internal and external challenges faced by the WEF. Internally, as far as the concrete practice of the meeting is concerned, the event has reached such a gigantic scale that paradoxically this undermines the chances to make connections. At the core of the social myth of Davos lies the principle that each participant is thought to be part of a sufficiently important élite to have exclusive and non-discriminatory access to the most compact network of the world. Belonging to the community allows networking without any prearranged appointment. However, the huge size of the event and the number of meetings planned in advance has considerably undermined this principle. Prior insertion in the network largely determines the possibility of taking advantage of it. As Jacques Attali notes, the best strategy to organise your time in Davos is 'to accept in advance more invitations than the existing number of lunches and dinners and pick and chose at the last moment which one provides the best opportunity'. ${ }^{55}$ This type of behaviour considerably limits the range of incidental connections. Consequently, the Forum abolishes far fewer hierarchies than it pretends and its network is considerably less open than suggested.

The growth strategy pursued since the mid 1980s has also increased the visibility of the hidden face of the myth. Business deals and corporatist behaviour are far from new, but the weight of corporate interests in the panels and the means deployed to communicate and strike deals in Davos have lately been out of proportion to the WEF mission commitment of 'improving the state of the world'. This problem has become crucial since the end the 1990s. Media coverage of the meetings clearly reflects this shift. The newspapers viewed as the most prestigious by the world business community have themselves contributed to tarnishing the image of the WEF. In 2000 the Wall Street Journal and the Washington Post published in-depth investigations on the for-profit activities in which the supposedly not-for-profit WEF Foundation was involved.$^{56}$ Over the past few years the Financial Times has for its part started making ironic comments on the ability of the WEF to incarnate the general interest. In 2002, it described this as the 'Bono factor', in reference to the Irish rock star urging his fellow participants to pay more attention to the tragic situation of Africa:

The Bono factor is the anxiety among the Davos delegates to demonstrate that despite their extraordinary collective wealth and power ... they care about the blight of poverty in the world and want to do something about it. It is the Davos guilty conscience.... and yet. It is hard to escape the feeling that for all the earnest discussion and knotted brows, what Davos is really about 
for most participants is the chance to make connections and do business. $^{57}$

There can be little doubt that the size of the event and the declining public image of the Forum have induced a risk of defection of participants disappointed by the atmosphere of a besieged and overcrowded fortress. Several participants to the 2001 edition admitted to feeling rather troubled by the scale of security measures and determined to think twice about returning. ${ }^{58}$ In 2003 the organisers decided on 'Building Trust' as the core theme of the event, but the loss of trust in both internal corporate duties and the wider world could not offset the low turnout and sombre tone. ${ }^{59}$ Such trends could quickly jeopardise the financial basis of the Forum and seriously undermine its future since multinational corporations pay for all non-corporate participation and for the lavish Secretariat of the Foundation.

The WEF is also facing a crucial external challenge. Such a compact and confined gathering constitutes a quasi-natural target for the social movements opposing neoliberal globalisation. After the successful struggle against the planned Multilateral Agreement on Investment (MAI) in 1998, the big demonstrations that took place during the Group of Seven (G7) meeting of Cologne in 1999 and the battle of Seattle during the World Trade Organization Ministerial Meeting later that year, the 2000 edition of the WEF faced, for the first time, a well-organised opposition. The Swiss NGO 'Declaration of Bern' coordinated the planning of a counter-forum, called 'Public Eye on Davos', in which a dozen other NGOs took part. By echoing the principles of freedom, democracy and transparency of the official Forum, the organiser of the counter-forum skilfully gained the attention of dozens of bored journalists. The image of a group of activists in snowsuits and looking at the Kongresshaus of the Forum through their binoculars circulated around the world and brought a touch of originality to the yearly ritual of the Davos press coverage. As is the case with most major summits around the world, the counter-summit was accompanied by demonstrations that from a discrete beginning in the early 1990s quickly gained importance by the end of the decade. Geographical conditions and security measures combine to bar large demonstrations in Davos itself, and yet, in 2001, violent clashes took place when the demonstrators were turned back by the security forces and marched on Zurich, the financial centre of Switzerland. In 2003, the same scenario took place and affected Bern, the capital of the country.

In the context of these internal and external pressures, the future of the WEF is at risk. The Foundation has been planning two types of measures to overcome these difficulties. First, to keep the social myth of the annual meeting, the preservation of the club atmosphere safe from the external world must be secured at all costs. Whilst the security bill was a few hundred thousand Swiss francs (CHF) in 1997, it soared to several millions in 2001. With the dramatic consequences of 11 September 2001, negotiations on the security bill for 2002 could not be finalised in time and the organisers were worried that huge insurance fees would dissuade most of the regular American participants. For the first time in more than 30 years, the annual meeting of the WEF abandoned Davos and moved to New York. Although the move was sold to the public as 
an act of solidarity to a wounded city and country, the financial and security bases of the move proved to have harmful consequences: a global city like New York could not provide the conditions for a massive club atmosphere; it has no unity of place, no unity of action and no unity of time. Participants took advantage of doing other business located in New York and spent a minimum of time within the actual arena of the Forum. Burdensome negotiations took place to bring the meeting back to Davos in 2003 with, this time, a security bill of around CHF15 million, almost entirely covered by local, regional and federal public finance from Switzerland. Whilst the Forum seems non-exportable (except to another confined resort offering the same privileged target for demonstrations), the social and financial cost of assuring its security will remain an object of acute debate. ${ }^{60}$

The second set of measures being implemented by the leaders of the Foundation involves a superior level of institutionalisation. The aim of this move is to overcome the ephemeral aspect of the social myth conveyed by the annual meeting and create what I call hegemonic workshops. Small groups of transnational élites wrap up initiatives whose direct impact on the course of specific issues of world politics would serve as examples of consensual solutions to conflicting situations. As Klaus Schwab put it, the WEF should now 'shift away from an event-oriented organisation towards a knowledge- and process-driven organisation' ${ }^{61}$ Likewise, the Director of Communication and Public Affairs of the WEF replicates the message by stating that 'the WEF has succeeded as facilitator of initiatives. Now, it's time to be more outcome oriented and become a catalyst. ${ }^{62}$ Ahead of the meetings, the participants receive stacks of material, including analytical notes, original essays and various aggregated data provided by big consulting firms such as Oxford Analytica and Accenture. The Secretariat of the Foundation has been restructured to include a system of knowledge dissemination. Members are solicited to develop projects between themselves, which, if successful, are later subsidised by the Foundation. Task forces and initiatives of all sorts have been launched and heavily publicised over the last few years. While many of them drift apart successively, some of them vie with other initiatives to bring new evidence to influence the policy agenda. In this domain, the self-proclaimed flagship of the WEF is the document presented by the Digital Divide Task Force to the 2000 Okinawa G7 Summit as a draft proposal for ensuring the inclusion of poor countries in the so-called digital economy.

Notwithstanding the genuine steps taken by the Forum to react to the new challenges it faces, three problems, at least, prevail. First, private meetings and connections to be made will for self-evident reasons remain the prime motivation to pay the costly bill to take part in the events organised by the Forum. Hegemonic workshops could at most complement, but in no way supplant the annual and/or regional meetings. Second, a hegemonic process supposes the ability of the ruling élite to include broader elements of the society in the goal to obtain widespread acceptance of its claim to embody the general interest. This, in turn, implies relinquishing cleavages that have contributed to the success of the social myth of Davos. The club atmosphere has, indeed, been broadened towards individuals from subordinated interests. In the context of a growing 
hostility, in 2000 the Forum invited a few NGO leaders to join the five or six union leaders regularly present at Davos. In 2001 around 30 of them took part in the event and represented around one per cent of all participants. They included the best known critics of the moment, such as Thilo Bode of Greenpeace, Martin Khor of Third World Network, Lori Wallach of Public Citizen, and Vandana Shiva of the Research Foundation for Science. They all publicly denounced the repressive policies used against the demonstrators and collectively laid down a number of conditions for renewing their participation in the Forum. As a result, in 2002, most were either not invited or declined the offer. ${ }^{63}$ Greenpeace, for instance, rejected the invitation once it was clear that its representatives would be kept out of the meetings of the task force to which they were officially associated. The mutual trust on which the whole club atmosphere hinges was clearly destroyed ${ }^{64}$ For activist leaders, the place to be henceforth was not Davos, but Porto Alegre in Brazil, with its competing World Social Forum.

Third, the new institutional processes of the Forum not only exclude subordinated interests of transnational capital; they also fail to raise class consciousness among the very individuals who take part in those practices. Most of the initiatives use the workforce of those constituents of the Foundation called 'Global Leaders of Tomorrow'. These so-called GLTs are individuals of less than 40 years old who are considered to have demonstrated significant skill in their respective domain of excellence, be it economic, political, academic, cultural or religious. About a hundred of them are invited each year to take part in the annual meeting for five years running. To ensure being part of the club beyond this timeframe, either the company they lead is given the status of member by the Foundation and pays its fees, or, as individuals, they get the status of Forum Fellow and continue to be invited. However, if they have not added what is considered a significant value to the activities of the Forum within this deadline, they are excluded. Such rules reinforce personal ambitions and competing practices in the work of the task forces. As one GLT put it, "there is too much ego, with individuals who always try to manipulate the project in their own interest. Under these conditions, you'd better remain cautious and not distribute information that others will just use to raise their own profile. ${ }^{65}$ Such behaviour reflects an exemplary lack of class consciousness. It prevents GLTs from overcoming their individual interests in the collective interest of capital coordination. It strongly contradicts the effort of the leaders of the WEF Foundation to develop hegemonic workshops which would transcend the inherent weakness of the social myth of the annual meetings.

\section{Conclusions}

This article has analysed the World Economic Forum as a test case of private authority exercised on a global scale by informal and weakly institutionalised non-state actors such as transnational élite clubs. The World Economic Forum presumably reflects the archetype of the most exclusive and powerful transnational élite club. Its success story hinges on the opportunities for networking within the three unities of place, time and action of the annual meetings in, or of, 'Davos'. The sense of an exclusive community is particularly important for 
all the second-tier businesspeople paying a costly participation fee for lining up meetings, cutting deals and savouring the opportunity to meet top political figures. Among high-profile élites, it is also an efficient infrastructure for piling up appointments, solving urgent matters and ensuring a broad repercussion of their message in élite circles, the media and wider public opinion. Yet the article suggests that the World Economic Forum faces intrinsic limits to its power. I have drawn upon Sorel's concept of social myth to examine how the actual practices and organisational principles of transnational élite clubs impair their power. Following Sorel's argument, the collective passion underpinning the energy released during the meetings of the WEF lacks institutional basis. Despite the continuing force of attraction it exerts on world leaders, recent developments give further evidence of this weakness: the bigger the suggested influence of a transnational élite club, the greater the problems to legitimise its informal power. The sheer size of the meetings, the huge media coverage and better organised opposition all contribute toward jeopardising the peculiar club atmosphere that made the WEF so successful. In this respect the current attempt by the officials of the Foundation to bridge the gap between the loose influence of a closed club and a more focused engagement with states, intergovernmental organisations and society at large appears largely irrelevant.

Three broader implications for the study of our present world may ensue from the approach developed in this article. First, the insight of Sorel's concept of social myth helps us to develop a better understanding of global change. As Cox has pointed out, 'the real achievement of [international political economy] was not to bring in economics, but to open up a critical investigation into change in historical structure ${ }^{66}{ }^{66}$ Transnational historical materialist approaches have enabled scholarship to open up the sovereign state and situate the agents of change in terms of their relations to the structures of capitalist societies. Herein lies the relevance of class analyses for shedding light on the agents of globalisation regarding the inequality between those who control the financial and material basis of social life and those who create the surpluses to accumulate these means. The concept of social myth specifies the conditions for strengthening class consciousness by exploring the unique undertaking that occurs when individuals are involved in a major collective action clearly separating social groups. The mobilisation draws its strength from the situation of total cleavage in the sense of identity shared by people between themselves and towards the future. As we have seen, however, Sorel recognised that structural change in society would only occur if deeper institutional processes are also engaged.

This brings us to the second point: the notion of power. The Gramscianinspired concept of hegemony has now gained wide currency among scholars who seek to explore the comprehensive trade-offs taking place within the structural power of the global political economy. As Germain and Kenny have highlighted, however, a considerable amount of reinterpretation is necessary when transposing Gramscian concepts. ${ }^{67}$ There is a lack of clear understanding of the mechanics of hegemony, the concrete course that eventually leads to the implementation of a global order. Here again Sorel's concept of social myth contributes to a more socialised understanding of Gramscian-inspired analyses of hegemonic power and counter-hegemonic movements. As we have seen, social 
myths and hegemonic leadership can be appraised as two ends of a continuum between, on the one hand, vain agents overemphasising their ability to transform the world and, on the other, public institutions providing consent to the dominance of a particular configuration of forces.

The third point relies more specifically on the private dimension of power. Private actors have now firmly entered into the scholarship on globalisation. Yet, as Higgott et al. remark, 'depending on the particular understanding of globalisation adopted, the exact distribution of authority between actors differs'. ${ }^{68}$ The clear assumption is that the current realignment cannot simply be explained by the empirical context of the dramatic changes that have recently taken place on a world-wide scale. It is rather the theoretical perspective adopted that will underpin the power of new categories of non-state actors in the global realm. By pointing to the intrinsic limits of power capabilities divorced from the legitimate institutions of public life, Sorel may prove helpful in shifting the theoretical agenda away from providing evidence of power towards what I have called a hermeneutics of limits. In this regard transnational élite clubs constitute a model. They bring together individuals who are in de facto positions of power, even though a whole range of hierarchies is also present behind their closed doors. Sorel's perspective is important in relativising the conclusions drawn by transnational historical materialist approaches on this issue. Elite clubs do indeed provide informal platforms for networking and delicate economic and political negotiations. They also provide a useful milieu for individuals concerned to bring about the strategic advancement of a cosmopolitan, long-term future of capitalism. Yet their role in the public sphere clashes with the limits of their organisational principles. Divorced from society at large and with no formal devolution of power, paradoxically their influence emphasises their lack of legitimacy and therefore their inability to compete in the public debate. Sooner or later this situation will foster the development of contending forces disputing their very existence.

This reasoning can be extended to other private actors claiming wider public recognition on various issues and forms of international authority. Private authority assumes that the power vested in private property and the autonomy of the subject should not necessarily be mediated by the public sphere in order to be socially recognised. Unlike classical liberalism, it claims public authority without directing its resources towards the conventional institutions of the public sphere. The case for enmeshing public and private realms by accepting or delegating public tasks to private actors is generally made on expertise, efficiency or issue-oriented rationales. The catchwords of 'best practice', multitiered global governance, or multi-stakeholder dialogue rest on this assumption. Private and public actors are tied, however, by opposite types of accountability. The delegation of public tasks to private experts and corporate leaders confers on them a status equivalent to that of political leaders. Yet it denies them an equal liability towards citizens. It is in this respect that one must remain wary of any claims that attempt to abolish the distinction between private and public authority. 


\section{Notes}

This article draws on work conducted under the auspices of a Swiss National Science Foundation (FNS) Fellowship for Advanced Researchers, Public and Private Authority in Global Trade Governance. I am grateful to the FNS for its support and to the members of the Department of International Relations and Politics of the University of Sussex and the Centre d'Etudes et de Recherches Internationales (CERI) in Paris, as well as to the anonymous referees for their comments on earlier versions of this paper. I also would like to thank Paul McCarrick and Liesl Graz for their invaluable help with the language.

1. The following account relies on official archives, private archives, and interviews conducted with a dozen individuals who were closely related to the early history of the WEF, as well as around 30 individuals who took part more recently in WEF meetings. I also mailed a questionnaire to 715 business individuals who took part in both the 2000 and 2001 annual meetings of the WEF. This move highly irritated the Director General of the WEF who without delay enjoined me to stop contacting members of the WEF and, very likely, notified them against my solicitation. The bias produced by this context, the limited access to e-mail addresses and the weak rate of return suggest that I could not rely on sensible quantitative analysis. All non-English quotations are translated by the author.

2. Ignacio Ramonet, Le Monde Diplomatique, March 1996, p. 1.

3. Quoted in 'I, Klaus', Wired Magazine, 7 December 1999.

4. See, in particular, the following edited volumes: A. Claire Cutler, Virginia Haufler \& Tony Porter (eds), Private Authority and International Affairs (SUNY Press, 1999); Rodney Bruce Hall \& Thomas J. Biersteker (eds), The Emergence of Private Authority in Global Governance (Cambridge University Press, 2002); Richard Higgott, Geoffrey Underhill \& Andreas Bieler (eds), Non-State Actors and Authority in the Global System (Routledge, 1999); and Daphné Josselin \& William Wallace (eds), Non-state Actors in World Politics (Palgrave, 2001).

5. Susan Strange, The Retreat of the State: The Diffusion of Power in the World Economy (Cambridge University Press, 1996), p. 95.

6. A. Claire Cutler. 'Locating “Authority” in the Global Political Economy', International Studies Quarterly. Vol. 43, No. 1 (1999), p. 61.

7. Diane Stone, 'Private authority, scholarly legitimacy and political credibility: think tanks and informal diplomacy', in: Higgott et al., Non-State Actors and Authority in the Global System, p. 219.

8. On its most general basis, structural power refers to the material and discursive structures which, intentionally or unintentionally, canalise the prospect of change on a transnational basis. See Stefano Guzzini, 'The use and misuse of power analysis in international theory', in: Ronen Palan (ed.), Global Political Economy: Contemporary Theories (Routledge, 2000), pp. 53-66.

9. Stephen Gill, American Hegemony and the Trilateral Commission (Cambridge University Press, 1990); Kees van der Pijl, The Making of the Atlantic Ruling Class (Verso, 1984); Kees van der Pijl, Transnational Classes and International Relations (Routledge, 1998); and Bastiaan van Apeldoorn, Transnational Capitalism and the Struggle for European Integration (Routledge, 2002). See also Dominic Kelly, 'Beyond Diplomacy: The International Chamber of Commerce and Global Governance', CSGR Working Paper, No. 74/01, University of Warwick, May 2001; and Leslie Sklair, The Transnational Capitalist Class (Blackwell, 2001).

10. To my knowledge, the only scholarly article specifically focused on the WEF studies its pedagogical relevance. It is based on secondary sources, except for those accessible on the website of the WEF. It argues that the WEF is a multifunctional case particularly good for encouraging students to compare competing narratives in the international political economy literature. See Geoffrey Allen Pigman, 'A Multifunctional Case Study for Teaching International Political Economy: The World Economic Forum as Shar-pei or Wolf in Sheep's Clothing?', International Studies Perspectives, Vol. 3 No. 3 (2002), pp. 291-309.

11. Wolfgang H. Reinicke, Global Public Goods: Governing without Government? (Brookings Institution, 1998); Justin Greenwood, 'Organized business and the European Union', in: Justin Greenwood \& Henry Jacek (eds), Organized Business and the New Global Order (Macmillan, 1999), pp. 93ff; and Margaret G. Herman et al., 'Who Leads Matters: The Effect of Powerful Individuals', International Studies Quarterly, Vol. 3, No. 2 (2001), pp. 83-131.

12. Stephen Wilks, 'Comparative capitalism and the political power of business', in: Susan Strange (ed.), Globalisation and Capitalist Diversity: Experience on the Asian Mainland (European University Institute, 1996), pp. 31-63; and William D. Coleman, 'Associational governance in a globalizing era: weathering the storm', in: J. Rogers Hollingsworth \& Robert Boyer (eds), Contemporary Capitalism: The Embeddedness of Institutions (Cambridge University Press, 1997), pp. 127-53. 
13. Ian R. Douglas, 'Globalisation as governance: towards an archeology of contemporary political reason', in: Aseem Prakash \& Jeffrey Hart (eds), Globalization and Governance (Routledge, 1999), pp. 134-60.

14. Higgott et al., Non-State Actors and Authority in the Global System, p. 6.

15. Robert Cox, with Michael G. Schechter, The Political Economy of a Plural World: Critical Reflections on Power, Morals and Civilisation (Routledge, 2002), p. 30.

16. Sklair, The Transnational Capitalist Class, p. x.

17. Karl Marx, Oeuvres: Économie I (Gallimard, 1965), p. 1238.

18. Stephen Gill, 'Structural change and global political economy: globalizing élites and the emerging world order', in: Yoshikazu Sakamoto (ed.), Global Transformation (United Nations University Press, 1994), p. 179.

19. Gill, American Hegemony and the Trilateral Commission, p. 122.

20. Antonio Gramsci, Cahiers de prison: Cahiers 10, 11, 12 et 13 (Gallimard, 1978), p. 421 (notebook 13, para. 30).

21. Van der Pijl, Transnational Classes and International Relations, p. 98.

22. Ibid., pp. 132 and 133.

23. Gill, American Hegemony and the Trilateral Commission; Apeldoorn, Transnational Capitalism and the Struggle for European Integration; and Bastiaan van Apeldoorn, 'Transnational Class Agency and European Governance: The Case of the European Round Table of Industrialists', New Political Economy, Vol. 5, No. 2 (2000), pp. 157-81.

24. Van der Pijl, Transnational Classes and International Relations, p. 134.

25. This perspective would require a semiological analysis following the writings of the French author Roland Barthes on the myth as a 'depoliticised voice'; see Roland Barthes, Mythologies (Seuil, 1957), pp. $229 \mathrm{ff}$.

26. Enrico Augelli \& Craig Murphy, 'Consciousness, myth and collective action: Gramsci, Sorel, and the ethical state', in: Stephen Gill \& James H. Mittelman (eds), Innovation and Transformation in International Studies (Cambridge University Press, 1996), p. 29.

27. Georges Sorel, Réflexions sur la violence (Seuil, 1990 [1906]), pp. 30, 216 and 126.

28. Michel Charzat, 'A la source du "marxisme" de Gramsci', Cahiers de l'Herne: Georges Sorel (Ed. de l'Herne, 1986), pp. 213-22, and Nicola Badaloni, Il Marxismo di Gramsci: Dal mito alla ricomposizione politica (Enaudi, 1975).

29. Sorel, Réflexions sur la violence, p. 120.

30. Cox, The Political Economy of a Plural World, p. 29.

31. Georges Sorel, La Révolution Dreyfusienne, 2nd edn (Rivières, 1911), p. 20.

32. Gramsci criticises Sorel for being too spontaneous in identifying the general strike as the key social myth of contemporary history as compared to the significance of the party and the state in the process of political change. See Gramsci, Cahiers 10, 11, 12, 13, pp. 354-5 (notebook 13, para 1).

33. Charzat, 'A la source du "marxisme" de Gramsci', p. 219.

34. Antonio Gramsci, Cahiers de prison: Cahiers 6, 7, 8 et 9 (Gallimard, 1983), pp. 278-80 (notebook 8, para 36).

35. Kees van der Pijl, 'The Unmanageable World: Structures of Determination in Contemporary Global Change', European Journal of International Relations, forthcoming.

36. Lewis Lapham, The Agony of Mammon (Verso, 1998).

37. Interview with Jacques Attali, Paris, 26 April 2001.

38. Confidential interview, Davos, 25 January 2001.

39. http://www.weforum.org/site/homepublic.nsf/Content/Our + History.

40. Max Daetwyler, 'Case study: the Centre d'Etudes Industrielles (CEI), Geneva', in: Milan Kubr (ed.), Managing a Management Development Institution (International Labour Organisation, 1982); and JeanLouis Barsoux, INSEAD: From Intuition to Institution (Macmillan, 2000), p. 26.

41. CEI Report, June-July 1969, p. 3. Interviews with Victoria Curzon Price, Geneva, 9 January 2001; Max Daetwyler, Geneva, 8 February 2001; Jean-Claude \& Crista Maria Haenni, Gordes (FR), 23 June 2001; and Bohdan Hawrlylyshyn, Geneva, 11 January 2001.

42. The Honorary Chair of the meeting was George P. Baker, former Dean of the Harvard Business School; the opening address was given by Otto von Habsburg, the heir of the Austrian crown turned fervent patron of the European integration movement. The 14 members of the Advisory Board were European entrepreneurs having close ties with national business interest associations. The speakers from American business schools included Hermann Kahn, Director of the Hudson Institute; Howard Perlmutter, from the Wharton School of Finance; and the well-known economist, John K. Galbraith; the European and American business leaders included Jacques Maisonrouge, chief executive officer of IBM; Gustaff 
Gillenhammar, CEO of Volvo; Marc Wallenberg, a member of the core family of Swedish capitalism; and Aurelio Peccei, CEO of Olivetti. See Centre d'Études Industrielles, European Management Symposium, First European Management Symposium, Davos, Switzerland, January 24-February 7, 1971. On the reputation of the CEI, see Claude Rivière, 'Wider Training for Wider Markets', Vision, July/August 1972, pp. 87-91.

43. Duri Capaul, International Education Services AG, Chur, to Bob Hawrylyshyn, Director, Centre d'Études Industrielles, 9 June 1970 (Archives de l'Université de Genève, 1990/4/164). International Education Services AG was incorporated in the canton of Graubunden, Switzerland, on 12 May 1970. The company changed its name on 8 July 1988 to " "World Link" Communication Development', and again on 5 January 2000 to 'World Communications Development'. Since 12 February 2001 Klaus Schwab and his wife have no more responsibilities in the company (Registre du Commerce du Canton des Grisons, inscription No. CH-350.3.004.480-7).

44. 'Davos Symposium highlights CEI 25th year', CEI Report, No. 8, March 1971.

45. 'Erste Europäisches Management Symposium', Neue Berner Zeitung, 17 February 1971, emphasis in original.

46. Registre du Commerce du Canton de Genève, Switzerland, inscription No. CH-350.7.000.234-1.

47. The total income of the WEF more than doubled in the second half of the 1990s: it was 30 million Swiss francs in 1994-5 and reached 63 million in 2000/01. Inscription fees now represent less than 40 per cent of the earnings of the Foundation. See World Economic Forum, Annual Reports, 1998-9, p. 3 and 2000-1, p. 3.

48. Interview with Henri Schwamm, Geneva, 6 March 2001.

49. According to one participant, the Foundation gives to the 'Forum Fellows' invited for the first time the limited responsibility of animating a dinner table. A collaborator of the WEF present at the dinner has the task of reviewing their performance to report on a possible new invitation with a higher profile in the morning and afternoon discussion panels.

50. Detailed data can be found in Public Citizen, Davos World Economic Forum: Pricey Corporate Trade Association Loses Its Camouflage, Washington D.C., 31 January 2002.

51. Guy de Jonquières, Lionel Barber \& Hugh Carnegy, 'Davos has "lost” its rarefied atmosphere', Financial Times (online edition), 4 February 2002.

52. This was notoriously the case with Mexico in 1994, Indonesia in 1997, Russia in 1998 and Argentina in 2001.

53. Confidential interview, Davos, 25 January 2001.

54. Klaus Schwab, conference at the American International Club of Geneva, 14 November 2000.

55. Interview with Jacques Attali, Paris, 26 April 2001.

56. 'Davos chief dabbles in for-profit firms, raising questions about Forum's priorities', Wall Street Journal, 27 January 2000, pp. 1 and 8; and 'Entrance fees to the marketplace of ideas; high paying companies get some prime exposure at high-powered Davos conference', Washington Post, 24 January 2000, p. A15.

57. 'Dispatches', Financial Times (online edition), 1 February 2002; and 'Rock star to take O'Neill on AIDS trip', Financial Times, 4 February 2002.

58. Personal interviews.

59. 'Investment bankers fell like scapegoats', Wall Street Journal Europe, 27 January 2003, p. A4; 'Challenges on every front', The World: 2003. The World Economic Forum annual meeting opens today in Davos; Financial Times Special Report, 23 January 2003, p. 1; and 'Observer in Davos', Financial Times, 27 January 2003.

60. 'Le retour à Davos du World Economic Forum est programmé pour 2003', Le Temps (Geneva), 19 January 2002; 'Mehr Rechte für Polizei', Tages Anzeiger (Zurich), 29 November 2001; 'Finanzierung der WEF-Sicherheit noch nicht geklärt', Sonntagszeitung (Zurich), 11 November 2001; and 'Bündner Regierung rügt Aliesch; Kollegialitätsprinzip durch WEF-Sicherheitspapier verletzt', Neue Zürcher Zeitung (online edition), 20 August 2002.

61. Klaus Schwab, 'Opening Address to the Annual Meeting 2001', Davos, 25 January 2001.

62. Interview with Charles McLean, Geneva, 21 December 2000.

63. Telephone calls and personal correspondence with the author, January 2002.

64. Letter of Geird Leipold, Executive Director of Greenpeace International, to Klaus Schwab, 10 January 2002, available at http://www.greenpeace.org/politics/wef/wefmtg16jan2002.html.

65. Confidential interview, 12 April 2001.

66. Cox, The Political Economy of a Plural World, p. 79.

67. Randall Germain \& Michael Kenny, 'Engaging Gramsci: International Theory and the New Gramscians', Review of International Studies, Vol. 24, No. 1 (1998), pp. 3-21.

68. Higgott et al., Non-State Actors and Authority in the Global System, p. 5. 